\title{
The effect of microbial oil, evening primrose oil, and borage oil on rumen ciliate populations in an artificial rumen (Rusitec)*
}

\author{
S. Kišidayová ${ }^{1,4}$, K. Mihaliková ${ }^{1}$, Z. Váradyová ${ }^{1}$, A. Potkański ${ }^{2}$, \\ M. Szumacher-Strabel ${ }^{2}$, A. Cieślak ${ }^{2}$, M. Čertik ${ }^{3}$ and D. Jalč ${ }^{1}$
}

\author{
${ }^{1}$ Institute of Animal Physiology, Slovak Academy of Sciences \\ Soltesovej 4-6, 04001 Košice, Slovak Republic \\ ${ }^{2}$ The August Cieszkowski Agricultural University of Poznań, \\ Department of Animal Nutrition and Feed Management \\ Wolyńska 33, 60-637 Poznań, Poland \\ ${ }^{3}$ Faculty of Chemical Technology, Slovak Technical University \\ Bratislava, Slovak Republic
}

\begin{abstract}
Microbial (MO), borage (BO) and evening primrose (EPO) 5\% (wt/wt) oils were supplemented to a diet consisting of meadow hay and ground barley (60:40) for six days following a five-day adaptation period in an artificial rumen (Rusitec) inoculated with sheep rumen fluid having an Atype ciliate population. After the adaptation period, the following rumen ciliate genera and species were established: Entodinium spp., Dasytricha ruminantium, Eremoplastron bilobum, Diploplastron affine, Polyplastron multivesiculatum and Isotricha spp. (I. prostoma and I. intestinalis). The total ciliate population as well as the population of Eremoplastron decreased $(\mathrm{P}<0.05$ and $\mathrm{P}<0.01$, respectively) in the group supplemented with BO. In contrast, the population of Polyplastron increased $(\mathrm{P}<0.01)$ following BO supplementation. The populations of Dasytricha, Eremoplastron, and Isotricha spp. decreased $(\mathrm{P}<0.01)$ in the group with EPO supplement, in contrast to the population of Entodinium spp., which increased $(\mathrm{P}<0.05)$. MO supplementation decreased the populations of Eremoplastron and Isotricha spp. $(\mathrm{P}<0.01)$. None of the oil supplements influenced the population of Diploplastron.

The results of this study showed that the examined species of rumen ciliates had no uniform response to the tested oils. Responses strongly depended on the composition of oils and the resultant concentration of the main fatty acid components.
\end{abstract}

KEY WORDS: microbial oil, evening primrose oil, borage oil, rumen ciliates, artificial rumen

\footnotetext{
* Supported by the Grant Agency of the Slovak Academy of Sciences, Grant No. 2/6174/6 and the State Committee for Scientific Research (Poland), Grant No. 3 P06Z 05923

${ }^{4}$ Corresponding author: e-mail: kisiday@saske.sk
} 


\section{INTRODUCTION}

Microbial oil (MO), evening primrose oil (EPO) and borage oil (BO) are oils with high polyunsaturated fatty acid contents, especially gamma linolenic acid $\left(\mathrm{C}_{18: 3}, \mathrm{n}-6\right)$, which participates in the metabolism of a wide variety of important metabolites regulating critical biological functions. Little information was found about the use of these oils in ruminants and none about their effects on protozoa, especially rumen ciliates. Increasing the content of polyunsaturated fatty acids in meat and milk is, however, a strategy to improve the quality of ruminant meat and dairy products due to their positive action on human health. In contrast to rumen bacteria, the levels of $\mathrm{C} 18: 2$ and $\mathrm{C} 18: 3$ fatty acids are higher in rumen ciliate protozoa (Viviani, 1970; Emmanuel, 1974; O'Kelly and Spiers, 1990). Enhancing the population of ciliate protozoa may therefore also prove to enhance the production of polyunsaturated fatty acids.

The aim of this work was to determine the effects of $\mathrm{MO}, \mathrm{EPO}$, and $\mathrm{BO}$ on the rumen ciliate population in an artificial rumen.

\section{MATERIAL AND METHODS}

The oil supplements and the general rumen simulation technique (Rusitec), its operation, and experimental design were described by Jalč et al. (2005). Briefly, MO (fermentation vessel 2), EPO (fermentation vessel 3), and BO (fermentation vessel 4) were supplemented at a rate of $5 \%$ (wt/wt) of the diet consisting of meadow hay and ground barley (60:40) for six days following a five-day adaptation period in a Rusitec inoculated with sheep rumen fluid having an Atype ciliate population. Fermentation vessel 1 was not supplemented (control group). The chemical composition of the diet was presented by Jalč et al. (2005). Samples were collected on days 6-12 of Rusitec operation according to Kišidayová et al. (2001). After the adaptation period, the following rumen ciliate genera and species were established: Entodinium spp., Dasytricha ruminantium, Eremoplastron bilobum, Diploplastron affine, Polyplastron multivesiculatum, and Isotricha spp. (Isotricha intestinalis and Isotricha prostoma).

The results are given as arithmetic means \pm standard error of means (SEM). The statistical significances of the differences between control and treatment values were assessed using one-way analysis of variance with Dunnet's post test (GraphPad Prism version 4.0 for Windows, GraphPad Software, Inc., San Diego, $\mathrm{CA}$ ). Probability values of $\mathrm{P}<0.05$ were considered significant. 


\section{RESULTS AND DISCUSSION}

In the present study the most numerous species of the Entodinium genus were: Entodinium bursa, Entodinium caudatum, Entodinium longinucleatum, Entodinium furca monolobum, and Entodinium simplex. The effects of oil supplements on the ciliate populations are summarized in Table 1. The total ciliate population

Table 1. Effect of microbial oil, evening primrose oil, and borage oil on ciliate populations in an artificial rumen

\begin{tabular}{|c|c|c|c|c|c|}
\hline \multirow[b]{2}{*}{$\begin{array}{l}\text { Fermentation } \\
\text { vessel }\end{array}$} & \multicolumn{4}{|c|}{ Ciliate concentration, $\mathrm{n} / \mathrm{ml}$} & \multirow{3}{*}{ Statistics } \\
\hline & $\mathrm{V} 1$ & $\mathrm{~V} 2$ & V 3 & $\mathrm{~V} 4$ & \\
\hline Treatment & none & microbial oil & $\begin{array}{l}\text { evening } \\
\text { primrose oil }\end{array}$ & borage oil & \\
\hline Total concentration & $8065 \pm 325$ & $9018 \pm 471$ & $8846 \pm 769$ & $5963 \pm 168$ & V1 vs V4; $\mathrm{P}<0.05$ \\
\hline Entodinium spp. & $5600 \pm 318$ & $7050 \pm 440$ & $7400 \pm 751$ & $4125 \pm 167$ & V1 vs V3; $\mathrm{P}<0.05$ \\
\hline $\begin{array}{l}\text { Dasytricha } \\
\text { ruminantium }\end{array}$ & $1768 \pm 43$ & $1575 \pm 70$ & $1070 \pm 58$ & $1568 \pm 57$ & V1 vs V3; $\mathrm{P}<0.01$ \\
\hline $\begin{array}{l}\text { Eremoplastron } \\
\text { bilobum }\end{array}$ & $634 \pm 31$ & $373 \pm 24$ & $345 \pm 22$ & $196 \pm 28$ & V1 vs V2-4; $\mathrm{P}<0.01$ \\
\hline $\begin{array}{l}\text { Diploplastron } \\
\text { affine }\end{array}$ & $24 \pm 3$ & $21 \pm 4$ & $29 \pm 4$ & $19 \pm 4$ & NS \\
\hline $\begin{array}{l}\text { Polyplastron } \\
\text { multivesiculatum }\end{array}$ & $9 \pm 8$ & 0 & 0 & $38 \pm 4$ & V1 vs V4; $\mathrm{P}<0.01$ \\
\hline Isotricha spp. & $31 \pm 10$ & 0 & $3 \pm 3$ & $15 \pm 7$ & V1 vs $\mathrm{V} 2-3 ; \mathrm{P}<0.01$ \\
\hline
\end{tabular}

values are means \pm SEM; NS, nonsignificant

as well as the population of Eremoplastron bilobum was decreased in the group supplemented by $\mathrm{BO}(\mathrm{P}<0.05$ and $\mathrm{P}<0.01$, respectively $)$ in comparison with the control group. In contrast, the population of Polyplastron multivesiculatum increased following BO supplementation $(\mathrm{P}<0.01)$. The populations of Dasytricha ruminantium, Eremoplastron bilobum, and Isotricha spp. decreased $(\mathrm{P}<0.01)$ in the group supplemented with EPO, in contrast to the Entodinium spp. population, which increased $(\mathrm{P}<0.05)$. MO supplementation decreased the populations of Eremoplastron bilobum and Isotricha spp., respectively $(\mathrm{P}<0.01)$. None of the oil supplements influenced the population of Diploplastron affine. It can be said that the most sensitive species was Eremoplastron bilobum, whose population decreased on all supplementation regimes.

As BO is the richest in gamma-linolenic acid (24\%) among the tested oils, it seems that this fatty acid had an adverse effect on the total ciliate population. On the other hand, it was shown that linoleic acid had a stimulatory effect on the growth of Entodinium caudatum in in vitro culture (Kišidayová et al., 2005) which is in accordance with the present results. EPO, which contains $81 \%$ linoleic acid, had a stimulatory effect on the Entodinium spp. population. 


\section{CONCLUSIONS}

The results of this study show that the examined species of rumen ciliates did not show a uniform response to the tested oils. The responses strongly depended on the composition of the oils and resultant concentration of the main fatty acid components.

\section{REFERENCES}

Emmanuel B., 1974. On the origin of rumen protozoan fatty acids. Biochim. Biophys. Acta 337, 404-413

Jalč D., Potkański A., Szumacher-Strabel M., Cieślak A., Čertik M., 2005. Effect of microbial oil, evening primrose oil and borage oil on rumen fermentation in vitro. Vet. Med. Czech. 50, 480-486

Kišidayová S., Sviatko P., Siroka P., Jalč D., 2001. Effect of elevated cobalt intake on fermentative parameters and protozoan population in RUSITEC. Anim. Feed Sci. Tech. 91, 223-232

Kišidayová S., Váradyová Z., Michałowski T., Newbold C.J., 2005. Regeneration of cryoresistance of in vitro rumen ciliate cultures. Cryobiology 51, 76-84

O'Kelly J.C., Spiers W.G., 1990. Influence of host diet on the fatty acid composition and content of rumen protozoa in cattle. J. Protozool. 37, 190-193

Viviani R., 1970. Metabolism of long-chain fatty acids in the rumen. Adv. Lipid Res. 8, 267-346 